Marta Węgrzyn

\title{
RICOEUROWSKA „FILOZOFIA ROZPOZNANIA”
}

\begin{abstract}
[...] podmiot interpretujacy siebie interpretując znaki, to nie jest już cogito; to byt egzystujący, który odkrywa dzięki egzegezie swojego życia, że jest już ustanowiony $w$ byciu, nim jeszcze sam się ustanowi i należy do siebie ${ }^{1}$.
\end{abstract}

\section{WSTĘP}

Ricoeurowska filozofia człowieka koncentruje się wokół pytania: kim jest ten, który pyta o to, kim jest? Podejmuje ona kwestię tożsamości i łączy w sobie problem interpretacji z problemem „bycia sobą”. Interpretacja - w myśli francuskiego filozofa - staje się drogą prowadzącą do samorozumienia.

Dotychczasowo problem hermeneutyki pojawiał się tylko w obrębie egzegezy i miał na celu uchwycenie sensu analizowanego tekstu. Wraz z myślą Heideggera hermeneutyka weszła w obręb refleksji filozoficznej. Niemiecki myśliciel zauważył, że hermeneutyka niesie za sobą problem rozumienia w ogóle ${ }^{2}$.

${ }^{1}$ P. Ricoeur, Egzystencja i hermeneutyka, [w:] tenże, Egzystencja i hermeneutyka, przeł. E. Bieńkowska, H. Bortnowska, S. Cichowicz i in., PAX, Warszawa 1985, s. 190.

${ }^{2}$ „Hermeneutyka Heideggera, jako filozoficzna wskazówka programowa, uważana jest za radykalizację tkwiącej w rozumieniu tendencji do interpretowa- 
Już nie tylko pojmujemy rozumienie jako sposób poznawania, ale także jako sposób bycia ${ }^{3}$. Co więcej, Ricoeur, inspirując się myślą Heideggera uważa, że rozumienie świata i siebie prowadzi do autentycznego bytowania w świecie 4 .

Kres wiary w cogito, które samo się ustanawia, które w sposób bezpośredni i wyraźny ujmuje siebie, prowadzi do poszukiwania metody i fundamentu wszelkiej wiedzy o sobie. Aby człowiek dotarł do istoty swojego bytu, musi przebrnąć drogę interpretacji, której podlegają wytwory pozostawione przez niego (a także przez całą ludzkość) w świecie. Zostaje więc zastosowana metoda pośrednia, polegająca na analizie, a następnie interpretacji naszego

nia. Hermeneutyka, jak zaznacza Heidegger, jest rozumiana «w pierwotnym tego słowa znaczeniu wedle którego jest to interpretowanie» [M. Heidegger, Bycie i czas, przeł. B. Baran. PWN, Warszawa 1994, s. 53.] [...] Nie teoria wykładni, lecz sama wykładnia jest przedmiotem hermeneutyki, podniesionej do poziomu filozofii, ze względu na zdobywaną samo przejrzystość Dasein, przy czym filozoficzna praca wyjaśniania prowadzi jedynie do końca interpretację, której rozumiejące Dasein zawsze już dokonuje. Tym samym, hermeneutyka filozoficzna zmierza do samo-wykładni faktyczności, niejako do wykładni wykładni, dzięki czemu Dasein może stać się przejrzysty dla samego siebie. W wykładni przed Dasein zostają odsłonięte podstawowe struktury jego bycia": J. Grondin, Wprowadzenie do hermeneutyki filozoficznej, przeł. L. Łysień, WAM, Kraków 2007, s. 125-126.

${ }^{3}$ Tischner ujmuje to w następujący sposób: ,Rozumienie, które dawniej było przede wszystkim sposobem poznania jakiegoś pisanego lub mówionego «tekstu», okazało się być sposobem poznania człowieka i otaczającego go świata": J. Tischner, Rozumienie-dziejowość-prawda, [w:] Filozofia wspótczesna, pod red. tegoż, Instytut Teologiczny Księży Misjonarzy, Kraków 1989, s. 170.

${ }^{4}$ Ricoeur traktuje interpretację tekstu jako akt o znaczeniu egzystencjalnym: „[...] interpretacja jest procesem, w którym odsłonięcie nowych sposobów bycia - lub, jeśli ktoś woli Wittgensteina od Heideggera, nowych form życia - wyposaża podmiot w nowe możliwości poznania samego siebie": P. Ricoeur, Wyjaśnianie i rozumienie, [w:] tenże, Język, tekst, interpretacja, przeł. P. Graff, K. Rosner, PIW, Warszawa 1989, s. 186. 
dyskursu, naszych działań i ich zamierzeń. Interpretacja jest więc wedle Ricoeura nieustannym zwracaniem się ku sobie za pośrednictwem obiektywnych oznak swojego życia w świecie. „Samorozumienie siebie dokonuje się poprzez interpretację sposobów, w jakich sobość istnieje «poza sobą» - w świecie, w historii, w relacjach z innymi" ${ }^{5}$. Poddajemy interpretacji przejawy byciaw-świecie, nasze zewnętrzne akty i ich rezultaty. „Cogito może być odzyskane jedynie okrężnie przez odszyfrowanie [...] dokumentów jego życia" zachowań człowieka. Ricoeur pisze:

Sądzę stanowczo, że rozumienie jest nieodłączne od rozumienia siebie samego, [...] uważam, że symboliczne uniwersum jest środowiskiem samowyjaśnienia. $Z$ jednej strony oznacza to, że w wypadku, gdy znaki nie są środkiem, środowiskiem, medium, dzięki którym istniejący człowiek usiłuje znaleźć swoje miejsce, dokonać projekcji i zrozumieć samego siebie, zagadnienie sensu przestaje istnieć. Z drugiej strony zaś, na odwrót oznacza to coś zupełnie przeciwnego; znika bezpośrednie ujęcie siebie przez siebie, apercepcja wewnętrzna, przyswajanie sobie własnego pragnienia istnienia na krótkiej drodze świadomości, zamiast tego pojawia się cała droga interpretacji znaków. Krótko mówiąc, moją roboczą hipotezą jest konkretna refleksja, przez którą rozumiem cogito zapośredniczone przez całe uniwersum znaków ${ }^{7}$.

Jednym z etapów prowadzących do samorozumienia jest droga rozpoznania. Ricoeur zauważa: „W przypadku wszak «rozpoznania siebie» będzie chodziło także o tożsamość. Bo właśnie tożsa-

${ }^{5}$ M. Kowalska, Dialektyka bycia soba, [w:] P. Ricoeur, O sobie samym jako innym, PWN, Warszawa 2003, s. XXXII.

${ }^{6}$ P. Ricoeur, Egzystencja i hermeneutyka..., s. 197.

${ }^{7}$ P. Ricoeur, O interpretacji. Esej o Freudzie, przeł. M. Falski, Wyd. KR, Warszawa 2008, s. 237. 
mość rozumiana jako tożsamość osoby, będzie stawką rozpoznania [...]"'. Rozpoznanie samego siebie staje się dla człowieka wyzwaniem i wymaga osobistego zaangażowania. Rozpoznać siebie samego to dotrzeć do zagadki własnego działania i myślenia.

\section{ROZPOZNANIE JAKO IDENTYFIKACJA}

Warunkiem uznania/potwierdzenia swojej podmiotowości, a także podmiotowości innego, jest rozpoznanie. Rozpoznaję innego jako różnego ode mnie i rozpoznaję siebie w pełni swej sobości, jako podmiot działający, myślący i cierpiący. Pojęcie rozpoznania (reconnaissance) jest terminem wieloznacznym, stąd też we wstępie do książki Drogi rozpoznania Ricoeur odwołuje się do trzech znaczeń tego słowa:

I. Rozpoznawać (przedmiot) za pomocą rozumu, myśli, kojarząc go ze związanymi z nim obrazami i postrzeżeniami, odróżniać, identyfikować, rozpoznawać dzięki procesowi pamięci, osądowi, lub działaniu.

II. Przyjmować, uznawać za prawdę.

III. Przyznawać z wdzięczności, że jest się komuś za coś (opinię, czyn) zobowiązanym?.

Problematyka rozpoznania zajmuje się więc takimi zagadnieniami jak: poznanie jednostki lub poznanie przedmiotu, a także rozpoznanie tożsamości indywiduum na poziomie „tego samego" i „innego”. Dokonane przez Ricoeura analizy leksykograficzne kierują go w stronę filozofii rozpoznania. Owa filozofia ma w sobie, jak zauważa francuski filozof, trzy kręgi sensów filozoficznych: krąg kantowski, krąg bergsonowski i krąg heglowski. To, co

\footnotetext{
${ }^{8}$ P. Ricoeur, Drogi rozpoznania, przeł. J. Margański, Wyd. Znak, Kraków 2004, s. 14.

${ }^{9}$ Tamże, s. 7.
} 
interesuje Ricoeura w sposób szczególny to różnica, jaka istnieje między rozpoznaniem a poznaniem, a także różnica między identyfikacją a odróżnieniem. Poznanie odnosi się do poznania czegoś po raz pierwszy. Poznajemy coś jako nowe, a ściślej jawi nam się to, jako coś, czego jeszcze nie znamy. Z nieznanym nam obiektem postanawiamy nawiązać relację, która w pierwszej kolejności jest relacją poznawczą. Natomiast rozpoznać coś to ustosunkować się do czegoś, co już nam znane; rozpoznać to niejako odsłonić na nowo, zidentyfikować. Różnica, jaka zachodzi między identyfikacją a odróżnieniem, niesie za sobą problem tożsamości i inności. Identyfikacja to poznanie (na podstawie konkretnych cech) tego co identyczne (takie samo), gdy z kolei odróżnić coś to odróżnić jedną rzecz od drugiej, wykazać, że między owymi rzeczami występuje kategoria inności („tego, co inne”). Odnośnie pary identyfikować-odróżniać, francuski filozof pisze: „Rozpoznać coś jako takie samo, identyczne ze sobą, a nie od siebie inne, oznacza zarazem odróżnić to od wszystkiego innego" ${ }^{10}$.

Punktem wyjścia jest dla Ricoeura powiązanie słowa „rozpoznanie” z terminem „poznanie”, pojmowanym jako kognitywne działanie $\mathrm{w}$ świecie, by następnie termin ten odłączyć od procedury pojmowania i połączyć go z terminem „uznanie”. Uznanie rozumiane jest tu dwuaspektowo: jako rozpoznanie tożsamości innego podmiotu, mamy więc do czynienia z uznaniem wzajemnym, a także jako uznanie samego siebie, a więc rozpoznanie własnej tożsamości. Ricoeura interesuje zastosowanie słowa „rozpoznanie", a ściślej strona czynna i bierna tego czasownika, czyli „rozpoznawać coś” bądź „zostać rozpoznanym”. Rozpoznanie oznacza więc akt filozoficzny i „zyskuje status coraz bardziej

${ }^{10}$ Tamże, s. 13-14. 
niezależny względem zdolności poznawczej [cognition] jako zwykłego poznania [connaissance]"11.

Szczególnie ważne jest tu zagadnienie rozpoznania-identyfikacji. Identyfikacja może dokonywać się bowiem na dwóch płaszczyznach: „w stosunku do siebie samego” i „w stosunku do czegoś innego/drugiego". W celu uściślenia problematyki rozpoznania Ricoeur odwołuje się do Kartezjusza i Kanta. Zarówno jednego, jak i drugiego filozofa cechują odmienne koncepcje rozpoznania. Kartezjańskie identyfikowanie kojarzone jest z odróżnieniem, gdy tymczasem Kant podporządkowuje kategorię identyfikowania łączeniu (identyfikowanie to dla Kanta łączenie rzeczy).

Rozpoznawać w ujęciu Kartezjusza to przede wszystkim odróżniać za pomocą rozumu i myśli. Rozpoznać to „odróżnić prawdę od fałszu", ustrzec się przed zbłądzeniem. Z kolei rozpoznanie u Kanta wiąże się z czasem. W przypadku podmiotowości Kant odwołuje się do czasu „bycia w świecie wraz z jego realnymi zmianami" ${ }^{2}$. Identyfikacja jest nawiązaniem relacji w kontekście czasu. Rozpoznanie „ukazuje [...] jedność świadomości wobec przedmiotu" ${ }^{13}$. W takim ujęciu rozpoznanie boryka się z tym, co „zmodyfikowane” nie do poznania.

Rozpoznanie traktujemy jako diagnozę. Podmiot zarówno wobec siebie, jak i wobec drugiego dokonuje rozpoznania, na podstawie wcześniej przeprowadzonego rozeznania, pewnego obiektywnego „badania”, polegającego na weryfikacji pewnych cech, przejawów, działań. Rozpoznanie jest więc rezultatem procesu polegającego na poznaniu, odróżnieniu i sprawdzeniu, którego

\footnotetext{
${ }^{11}$ Tamże, s. 13.

${ }^{12}$ Tamże, s. 32.

${ }^{13}$ Tamże, s. 34.
} 
celem jest przede wszystkim identyfikacja określonej jednostki (czy też przedmiotu), a także pełne uchwycenie cech świadczących o inności podmiotu.

\section{ROZPOZNANIE SIEBIE SAMEGO}

Ricoeur zaczyna swoje rozważania od stwierdzenia, że rozpoznajemy siebie przy udziale drugiego człowieka. Rozpoznanie staje się „udziałem człowieka «działającego i cierpiącego» jako człowieka «zdolnego» do pewnych dokonań"14. Zanim więc przejdziemy do omówienia procesu rozpoznania siebie samego, powinniśmy uwzględnić rozpoznanie drugiego człowieka. Francuski filozof pisze:

W przypadku rzeczy rozpoznanie polega w znacznej mierze na identyfikowaniu za pomocą cech ogólnych bądź specyficznych; jednak pewne przedmioty nam bliskie mają swego rodzaju osobowość, która sprawia, że rozpoznawanie ich polega na wczuwaniu się w nie w relacji nie tyle ufności, ile współudziału. Osoby z kolei rozpoznają się głównie za pomocą cech jednostkowych ${ }^{15}$.

Stąd też ja, jako osoba posiadająca zdolności poznawcze, jestem w stanie rozpoznać drugiego także jako osobę i uznać jego podmiotowość. Francuski filozof odwołuje się w swoich badaniach nad rozpoznaniem drugiego do Husserlowskich Medytacji kartezjańskich $^{16} \mathrm{i}$ stwierdza, że relacja między podmiotem poznającym

${ }^{14}$ Tamże, s. 58.

${ }^{15}$ Tamże, s. 53.

${ }^{16}$ Ricoeur, równolegle z odwołaniem się do Husserlowskiej fenomenologii percepcji, przywołuje Lèvinasowską fenomenologię o charakterze etycznym. Francuski filozof nie opowiada się za jedną bądź drugą wersją „źródłowej asymetrii, w której punktami odniesienia są «ja» i «inny»”, ale uważa, że „istotne jest dla nas natomiast, jak usilnie każda z obydwu stron dąży do tego, aby przezwy- 
a podmiotem poznanym przechodzi drogę od jednostronności do wzajemności:

Sprawa konstytucji fenomenu „innego” przybiera zatem obrót paradoksalny: inność innego, tak jak każda inna inność, konstytuuje się we (in) mnie i ze mnie [à partir] (aus) mnie; niemniej obcy jako inny jest ukonstytuowany dla siebie właśnie jako ego, to znaczy jako podmiot doświadczenia, na tej samej zasadzie jak ja, jako podmiot zdolny postrzegać mnie samego, jako kogoś należącego do świata jego doświadczenia ${ }^{17}$.

Rozpoznanie drugiego oznacza przyznanie mu statusu podmiotu, uznanie go za podmiot, który dzięki swojej inności uzupełnia tożsamość poznającego. Inny w relacji wzajemności, za sprawą procesu rozpoznania uzyskuje, według Ricoeura, status przedmiotu

ciężyć utrzymującą się w pewien sposób w tle doświadczenia wzajemności asymetrię [...]": P. Ricoeur, Drogi rozpoznania..., s. 149. Należy również podkreślić, że Ricoeur nie podziela stanowiska Husserla odnośnie kwestii subiektywności, co więcej poddaje je krytyce, pisząc: „Husserl upatrywał w redukcji podstawowy akt filozoficzny, w którym świadomość odcina się od świata i konstytuuje siebie jako absolut; po redukcji wszelki byt staje się dla świadomości sensem i dlatego jest czymś względem niej relatywnym. Redukcja stawia cogito Husserlowskie w sercu tradycji idealistycznej, na przedłużeniu cogito Kartezjusza, Kanta, Fichtego. Cartesianische Meditationen idą jeszcze dalej w kierunku samowystarczalności świadomości i dochodzą do radykalnego subiektywizmu, który wyzwala się z solipsyzmu, walcząc z nim jego własną bronią i wywodząc innych z pierwotnej konstytucji ego cogito": P. Ricoeur, o pewnej filozoficznej interpretacji Freuda, [w:] tenże, Egzystencja $i$ hermeneutyka. Rozprawy o metodzie, przeł. E. Bieńkowska, H. Bortnowska i in., Instytut Wydawniczy PAX, Warszawa 1985, s. 265. Warto wspomnieć tutaj o Ricoeurowskiej serii artykułów poświęconych fenomenologii w książce: P. Ricoeur, A l'école de la phénoménologie, VRIN, 1986. Husserlowskim Medytacjom kartezjańskim poświęca artykuł: Étude sur les „Méditations Cartésiennes” de Husserl, [w:] Revue Philosophique de Louvain, Troisième série, t. 52, nr 33, 1954, s. 75-109.

${ }^{17}$ P. Ricoeur, Drogi rozpoznania..., s. 150. 
upodmiotowionego. Podmiot poznawany uzyskuje tę samą pozycję co podmiot poznający. W pierwszej kolejności dochodzi do rozpoznania podmiotu i uchwycenia jego cech podmiotowych, w drugiej kolejności do uznania owego podmiotu. Francuski filozof pisze: „Jedynie ja się ukazuję, staję się «obecny»; inny będący domniemaną analogią, zostaje «uobecniony»"18.

Po dokonaniu rekognicji, uznaniu tożsamości jakiejś osoby (lub rzeczy), Ricoeur przechodzi do kwestii rozpoznania siebie samego. Swoje rozważania opiera na literackich przykładach rozpoznania i poszukiwania swojej tożsamości. Bierze swojego czytelnika w podróż szlakami kultury europejskiej i europejskiej myśli filozoficznej, prowadząc rozważania „nad słowami oznaczającymi rozpoznanie, rolą znaków rozpoznawczych i rolą przebrań"19.

\section{4. „WALKA O ROZPOZNANIE”}

Ricoeur za bohatera „walki o rozpoznanie” wybiera Edypa $\mathrm{z}$ tragedii Edyp w Kolonie ${ }^{20}$. Francuski filozof analizując teksty Arystotelesa (głównie Poetykę) skupia się na trzech elementach, które wyróżniają tragedię ${ }^{21}$ : czyn tragiczny (działanie tragiczne), pery-

${ }^{18}$ Tamże, s. 151.

${ }^{19}$ Tamże, s. 61.

${ }^{20}$ Sofokles, Edyp w Kolonie, przeł. K. Morawski, Elan, Białystok 2002.

${ }^{21}$ Odwołując się do Antygony Sofoklesa, Ricoeur charakteryzuje grecką tragedię następująco: „[...] tematem tragedii jest działanie [...]. Jest więc ona dziełem samych działających i ich indywidualności. [...] ci działający pozostają na służbie duchowych mocy, które nie tylko ich przekraczają, lecz nadto same torują drogę archaicznym i mitycznym energiom będącym także niepamiętnymi źródłami nieszczęścia”. I dalej, wskazując na niefilozoficzne cechy tragedii pisze: „[...] wrogie mityczne moce wzmacniające rozpoznawalne konflikty ról; nie dająca się zanalizować mieszanina losowych przymusów i świadomych wyborów; oczysz- 
petię bohatera oraz rozpoznanie. „Tragedia [...] opowiada o jednym całkowitym działaniu ludzkim, [...] jakimś pełnym znaczenia czasowym odcinku dziejów jednego człowieka"22, w trakcie którego może nastąpić odwrócenie losu bohatera. Edyp i życiowy dramat, którego jest on uczestnikiem, wskazują tym samym na tajemniczy sens dziejów samego człowieka. U źródeł nieszczęść Edypa znajduje się przeznaczenie - nadrzędna siła rządząca światem. Klątwa, jaka od wieków ciążyła na rodzie Labdakidów, wyznaczyła przyszłą historię bohatera. Nic już nie zależało od jego postępowania, każdy czyn zbliżał go do spełnienia się przepowiedni. Walka, jaką podejmuje bohater, okazuje się słaba, zaś słuszna i rozważna decyzja (proairesis ${ }^{23}$ ) w rezultacie staje się pozorną. Kolejne czyny Edypa stają się realizacją tego, co zostało wcześniej przepowiedziane.

Czym jest zatem rozpoznanie? Rozpoznanie ujęte jest w tym utworze ,jako przejście od stanu niewiedzy do wiedzy”24. Tragizm Edypa polega właśnie na owym „przejściu”, jest konsekwencją dokonanej przez Edypa retrospekcji, rozpoznania samego siebie w połączeniu dramatycznych okoliczności z przeszłości. Tragizm Edypa jest także następstwem identyfikacji swojego działania, bowiem „bohater jest tym samym cierpiącym człowiekiem, który rozpoznał się przez działanie”25. Edyp staje się więc przykładem

czający skutek wywierany przez samo widowisko we wnętrzu namiętności, jakie ono rodzi": P. Ricoeur, Interludium, [w:] O sobie samym..., s. 400-402.

${ }^{22}$ Z. Adamczewski, Tragiczny protest, PIW, Warszawa 1969, s. 38.

${ }^{23}$ Proairesis - w ujęciu Arystotelesa słuszna decyzja życiowa podjęta pod wpływem rozwagi: W. Galewicz, Z Arystotelesem przez greckie tragedie, Wydawnictwo Literackie, Kraków 2002, s. 142-144.

${ }^{24}$ P. Ricoeur, Drogi rozpoznania..., s. 65.

${ }^{25}$ Tamże, s. 68. 
bohatera, który źródło swego samorozumienia upatruje w interpretacji swojego działania. Podstawowym warunkiem rozpoznania siebie staje się gotowość do przypominania sobie dokonanego czynu. Ricoeur analizując poczynania bohatera greckiej tragedii powołuje się na filozofię działania Arystotelesa, według którego działanie i postanowienie dążą do dobra. Z kolei źródło tego dobra „tkwi w nas samych, w naszych działaniach. Do tego się sprowadza najbardziej elementarny warunek tego, co nazywamy poznaniem samego siebie. Jego zasadniczą możliwość określa umocowanie celu dobra w działaniach stanowiących obowiązek człowieka jako takiego, nasz obowiązek"26. W związku z tym Ricoeur mówi o fenomenologii człowieka zdolnego, którego wyróżnia zdanie: „mogę zrobić”. Zdolność działania i podejmowania decyzji jest zdolnością samego podmiotu. Poprzez dokonanie danego czynu, a także możliwość refleksyjnego zwrócenia się ku sobie, podmiot jest w stanie dokonać tzw. aktu przypisania.

\begin{abstract}
Termin „przypisanie” podkreśla specyficzność atrybucji, która wszak dotyczy związku między działaniem a podmiotem działania, które on, jak się również mówi, posiada, które jest jego, które on sobie przywłaszcza. Przypisanie dotyczy [...] zdolności samego podmiotu do wskazania siebie samego jako tego, kto daną rzecz robi bądź zrobił².
\end{abstract}

Tożsamość osobowa, a tym samym rozpoznanie siebie związane jest z rozpoznaniem swojego działania i mówienia. W celu rozpoznania siebie podmiot dokonuje aktu refleksji nad swoim mówieniem i działaniem, opowiada o sobie, by w ten sposób rozpoznać się jeszcze bardziej w takim a takim akcie. W ten oto sposób pro-

\footnotetext{
${ }^{26}$ Tamże, s. 70-71.

${ }^{27}$ Tamże, s. 86.
} 
blematyka rozpoznania siebie łączy się z pamięcią i obietnicą, których celem jest odzyskanie oddalonej przeszłości. Podmiot rozumiany jest tutaj jako ten, który pamięta i rozpoznaję zarówno siebie samego, jak i to, co uprzednio zostało przez niego poznane. Problematyka rozpoznania siebie w kontekście pamięci i obietnicy polega na tym, że:

[...] w chwili urzeczywistnienia wspominanie i obiecywanie odmiennie sytuują się w dialektyce takożsamości [mêmeté] i tożsamości siebie [ipséité], dwóch konstytutywnych walorów tożsamości osobowej: w wypadku wspomnienia główny akcent pada na takożsamość, tak że w ogóle nie ma mowy o charakteryzowaniu tożsamości [identité] za pomocą tożsamości siebie [ipséité]; w wypadku obietnicy dominacja tożsamości siebie jest tak przemożna, że obietnicę chętnie przywołuje się jako jej paradygmat ${ }^{28}$.

Pamięć, która kieruje się w stronę przeszłości ma charakter wspomnienia, reminiscencji, z kolei obietnica jest składana z myślą o przyszłości i ma charakter prospektywny. W obydwu przypadkach mamy do czynienia z groźbą niespełnienia - w wypadku wspomnienia może to być zapomnienie, z kolei w wypadku obietnicy, niedotrzymanie słowa. Ricoeur pisze: „dzięki pytaniu «kto sobie przypomina?» rozpoznanie wspomnienia oznacza rozpoznanie siebie" 29 . Podobnie sprawa przedstawia się z kwestią dotrzymywania słowa; dotrzymywanie słowa świadczy o tym, że pomimo i wbrew występującym zmianom - zarówno tym wewnętrznym, jak i zewnętrznym - jestem wierny danemu słowu.

Podmiot dąży do rozpoznania siebie. Za sprawą retrospekcji tworzy opowieść o sobie samym. Miarą umożliwiającą dokonanie

\footnotetext{
${ }^{28}$ Tamże, s. 100.

${ }^{29}$ Tamże, s. 101-102.
} 
owego rozpoznania jest kryterium etyczne. Etos człowieka odpowiedzialnego chwyta taki modus bycia, w którym sprawdzenie prawdziwości realizuje się poprzez weryfikację lojalności podmiotu wobec jego wcześniejszych obietnic/zobowiązań. Zestawienie teraźniejszego „ja” z jego wcześniejszymi postanowieniami i ewaluacja efektów ich realizowania, rozstrzygają o odpowiedzialności osoby, a tym samym są jedyną drogą prowadzącą do niezafałszowanego rozpoznania. Owo rozpoznanie może zostać dokonane tylko w kręgu etyki i aksjologii ${ }^{30}$. Etos jest konieczny do tworzenia przez podmiot koherentnego wizerunku samego siebie.

Zasadniczym warunkiem rozpoznania siebie jest chęć dotrzymania danego słowa, przy czym wierność danemu słowu jest możliwa do sprawdzenia dopiero wtedy, gdy istniejący w czasie podmiot dokonuje retrospekcji. Za pomocą hermeneutyki siebie, a ściślej hermeneutyki swoich działań, podmiot jest w stanie dokonać rozpoznania siebie.

\section{ZAKOŃCZENIE}

Według mitu Edyp od urodzenia był naznaczony przez zły los ${ }^{31}$. Znając wyroki fatum i chcąc uniknąć przeznaczenia wpadł w jego objęcia. W przypadku Edypa tragedia była nieunikniona. Bohater nie miał wyboru: wszystko, czego dokonał, stało się już przedtem. Dramat Edypa to nie tyle dramat ojcobójstwa czy kazirodztwa, ile - jak zauważa Ricoeur - przede wszystkim „dramat prawdy”:

${ }^{30}$ Ricoeur nie rozpatruje wartości $\mathrm{w}$ aspekcie ontologicznym, odwołuje się raczej do ich praktycznej strony. Wartości pomagają ocenić działania podmiotu i są konieczne przy tworzeniu etosu człowieka odpowiedzialnego.

${ }^{31}$ J. Parandowski, Mitologia: wierzenia i podania Greków i Rzymian, Wydawnictwo Poznańskie, Poznań 1989, s. 150-152. 
Dramatem Edypa jest to, że przeklął człowieka, którego nie zna, a który zabił Laiosa i poślubił Jokastę, to problem identyfikacji, odmowa identyfikacji, skoro będzie próbował oskarżyć swojego szwagra, skoro oskarży kapłana, jest to więc problem nie-prawdy, walki o prawdę, walki o rozpoznanie siebie ${ }^{32}$.

Rozpoznanie prawdy dokonuje się poprzez cierpienie, bowiem tylko na skutek oślepienia bohater doznaje wewnętrznego widzenia. „Rozpoznanie siebie dokonuje się - jak zauważa francuski filozof - za cenę twardej nauki, zdobywanej w ciągu długiej podróży poprzez te stałe konflikty, których powszechność jest nieodłączna od ich każdorazowo nieprzekraczalnego umiejscowienia" ${ }^{33}$. Rozpoznanie siebie rozgrywa się w tragiczności, w działaniach bohatera. Rozważając kwestię udanego rozpoznania, Ricoeur pisze: „Mamy na myśli perypetię, której towarzyszy rozpoznanie, anagnosisi - w tragedii greckiej: Edyp rozpoznaje w sobie samym złowrogiego inicjatora nieszczęść, które spadły na miasto"34. Edyp dokonuje autorozpoznania, które „staje się «jasnością bohatera»" 35 .

Człowiek w filozofii Ricoeura to człowiek cierpiący i działający, człowiek rzucony w świat i partycypujący w świecie, to przede wszystkim człowiek poszukujący samego siebie. Rozpoznanie samego siebie staje się dla człowieka wyzwaniem i jest osiągalne na drodze interpretacji oznak swojego bytowania w świecie.

${ }^{32}$ P. Ricoeur, Konflikt hermeneutyk: epistemologia interpretacji, przeł. J. Skoczylas, [w:] tenże, Egzystencja i hermeneutyka, PAX, Warszawa 1985, s. 142.

${ }^{33}$ Tenże, O sobie samym..., s. 402.

${ }^{34}$ Tenże, Pamięć, historia, zapomnienie, Universitas, Kraków 2012, s. 567.

${ }^{35}$ J. Kott, Zjadanie bogów: szkice o tragedii greckiej, Wydawnictwo Literackie, Kraków 1986, s. 12. 


\title{
RICOEUR'S „PHILOSOPHY OF RECOGNITION”
}

\begin{abstract}
SUMMARY
The article is devoted to one of the central problems of philosophy, which is a human identity, based on Ricoeur's ,philosophy of recognition”. This French philosopher refers to literary examples of recognition and to search for identity. He chooses Oedipus as a hero of „struggle for recognition”. Oedipus' life drama shows a mysterious sense of human history. The source of hero's misery lies in the destiny - a superior force that rules the world. Confronting the fate and drama self-recognition is accomplished.
\end{abstract}

KEYWORDS

Ricoeur Paul, tragedy, Oedipus, destination, identification, recognition, identity 